purchase has now been completed. For the present, the Institution will use the top two floors of the new house for storage of books and apparatus, releasing valuable accommodation elsewhere for other purposes. It is proposed to let the lower floors, and to devote any income obtained to research purposes. Eventually, as the research activities are enlarged, it may prove necessary to occupy a larger part of the house.

\section{Royal Institution: Reconstruction of the Library}

Aвout April last it was noticed that a sinking had occurred of the ceiling of the Library on the first floor at the Royal Institution, and of the floor of Sir William Bragg's rooms immediately above. The ceiling, which was old and of timber construction, was found to be defective. It was temporarily propped, and at the end of the lecture season a thorough examination was made. An astonishing state of disrepair was discovered. Not only was the heavy timber ceiling defective, but also the brick walls upon which it was supported were cracked and broken in all directions. The examination was carried down to the rooms on the ground floor and here a similar state of affairs was revealed. When in 1799 the Royal Institution was founded, a large town house was purchased and considerably altered to suit its new purpose. Further alterations have been made at intervals. Vulliamy added the Corinthian column front in 1837 . In 1930 a large part of the building, including the lecture theatre, was completely reconstructed, but the Library and rooms below it were left untouched. These it has now proved necessary to rebuild, largely, it must be said, due to faulty workmanship in the past, as the various alterations to the structure have been made.

THE reconstruction is now in progress. The defective brickwork of the walls is being replaced, including that of the front wall, which is being worked at from the inside, so that the elevation to Albemarle Street will remain untouched. New fire-resisting floors are to be supported on a steel structure, which is being erected within the walls. The steelwork, the foundations for which are being carried to basement level, will also serve to strengthen the rebuilt walls. When completed, the rooms on the first and second floors will appear much as they were before, but advantage is being taken of the alterations to construct a large new research laboratory in the basement. The work is expected to be completed about April next, and it is understood that it will cost about $£ 12,000$.

\section{November Floods}

THE past week or so has been characterised by rains and floods of exceptional severity, extending over a widespread area in western Europe, including the Rhone Valley, the Riviera, parts of Switzerland and of Great Britain. At Avignon, in the south of France, a large section of the town was inundated in places to depths of so much as six feet, and the famous Pont d'Avignon has been seriously damaged. At Nîmes, the Rhone reached the record height of
26 feet, and about 125 square miles of the valley were submerged. As an unfortunate consequence of so disastrous a visitation, there has been much distress and several deaths among the inhabitants of Provence and Languedoc. One village, Aurlot, near Marseilles, has been almost destroyed, whilst in various districts, thousands of people have been rendered homeless. Damage has also been reportød from Fréjus and Hyères. In Switzerland, wide areas near Geneva have been under two feet of water, and it is stated that no such floods have been recorded since so far back as 1890 . The rainfall was particularly persistent and lasted without intermission for sixty hours.

IN Great Britain, inundations of considerable tracts have followed locally unprecedented rainfalls for November, the first seventeen days of the month having yielded about twice the amount of rain normally experienced at a number of places in the south of England. Flooded districts are reported from Swanage in Dorset and many parts of Kent and Sussex, while in the Midlands, the River Trent has overflowed its banks. The Thames valley has also been seriously affected. Presiding at the meeting of the Thames Conservancy Board on November 18, Lord Desborough, the chairman, said that the state of the river was causing some anxiety. The flow was exceeding the 'root figure' (when the river is flowing bank high) by a thousand million gallons daily. The 'root figure' for the discharge of the river is 4,500 million gallons a day measured at Teddington; the comparable November average is 1,486 million gallons a day. The rainfall in the Thames Catchment Area had been quite exceptional for the time of the year. In September, there was a rainfall of 4.59 inches; in October, 4.09 inches and for 17 days of November, $4 \cdot 11$ inches. The total for two and a half months was 12.79 inches. Looking back over previous records, Lord Desborough said he had not been able to trace a similar case. The unexpected and catastrophic occurrence of such floods serves to emphasise the importance of the national inland water survey, so repeatedly advocated in NATuRE, and now in the hands of a committee of the Ministry of Health, appointed nearly a year ago, under the chairmanship of Sir Henry Lyons. It is obvious that only by accurate and reliable records of floods can adequate precautionary measures be devised and undertaken so as to remove a serious menace to life and property.

\section{Brauner Memorial Lecture}

From the time of the founding of the University at Prague in 1347 by Charles IV, Bohemia has been an important centre of learning. Komenský, Purkyně and Mendel all attained fame beyond the frontiers of their country, but the first Czech chemist to gain world-wide recognition was Prof. Bohuslav Brauner, who died on February 14 of this year. He had been a student at Manchester under Sir Henry Roscoe in the 'eighties, and whilst in England began some of his famous researches on the rare earths. He came to acquire an international reputation also by his advocacy of Mendeléeff's Periodic Law, to the 